\title{
ANALISIS MINAT BELAJAR SISWA PADA MATERI KONSEP PECAHAN MATEMATIKA SISWA KELAS IV DALAM MASA PANDEMI COVID 19 DI SD 1 WRINGIN ANOM KECAMATAN JATIBANTENG KABUPATEN SITUBONDO TAHUN PELAJARAN 2020/2021
}

\author{
Mory Victor Febrianto', Nur Halimatus Zuhro ${ }^{2}$ \\ 1,2Dosen FKIP Universitas Abdurachman Saleh Situbondo
}

\begin{abstract}
Abstrak : Pembelajaran matematika di kelas-kelas saat ini masih kurang di minati oleh siswa-siswi terutama di sekolah dasar, Minat ini besar pengaruhnya terhadap belajar, karena minat siswa merupakan faktor utama yang menentukan derajat keaktifan siswa, bila bahan pelajaran yang dipelajari tidak sesuai dengan minat siswa, siswa tidak akan belajar dengan sebaik-baiknya, sebab tidak ada daya tarik baginya. Berdasarkan hasil observasi kelas IV di SDN 1 Wringin Anom yang di lakukan oleh peneliti, peneliti menemukan suatu masalah yaitu masalah yang sering dirasakan sulit serta kurang diminati oleh siswa dalam pembelajaran matematika seperti contoh siswa merasa jenuh dan kesulitan dalam memahami pembelajaran yang di sampaikan oleh guru. analisis minat belajar Matematika pada materi konsep pecahan di kelas 4 SD Negeri 1 Wringin Anom Kecamatan Jatibanteng dapat di pengaruhi beberapa faktor yaitu faktor internal dan faktor eksternal. Faktor internal meliputi faktor fisiologi dan faktor psikologi sedangkan faktor eksternal meliputi lingkungan keluarga, lingkungan belajar pada saat kegiatan luring. Dari faktor eksternal yang mempengaruhi adanya minat belajar siswa dari lingkungan keluarga berupa perhatian orang tua, lingkungan belajar pada saat kegiatan luring berupa kedisiplinan yang harus diterapkan pada saat kegiatan luring dilaksanakan. Dari faktor-faktor tersebut harus diberikan penanganan yang khusus agar peserta didik memahami untuk pembelajaran matematika hususnya pada materi konsep pecahan, tidak adanya minat belajar yang dialami oleh peserta didik didalam pembelajaran Matematika materi konsep pecahan pada akhirnya dapat diketahui dan ditemukan secara sistematis yang berlokasi di SD Negeri 1 Wringin Anom Kecamatan Jatibanteng Kabupaten Situbondo tahun ajaran 2020/2021.

Kata Kunci : Minat Belajar, Matematika, COVID-19
\end{abstract}

\section{PENDAHULUAN}

Minat belajar memegang peranan penting dalam belajar Minat merupakan sebuah ketertarikan terhadap sesuatu hal sehingga kita tergerak untuk melakukan hal tersebut. Minat harus ada dalam diri seseorang, sebab minat merupakan modal dasar untuk mencapai tujuan. Minat merupakan pangkal permulaan dari pada semua aktifitas. Vina (2016) berpendapat bahwasannya minat belajar besar sekali pengaruhnya terhadap belajar, karena dengan minat belajar, siswa berusaha untuk mengetahui suatu pelajaran dengan cara mengetahui, mengikuti, dan memahami 
pelajaran. Setiap siswa memiliki minat belajar dan kebutuhan yang berbeda dengan siswa lain. Terdapat banyak mata pelajaran disekolah dasar yang akan dipelajari oleh siswa salah satunya yaitu Matematika.

Pembelajaran matematika di kelas-kelas saat ini masih kurang di minati oleh siswa-siswi terutama di sekolah dasar, Minat ini besar pengaruhnya terhadap belajar, karena minat siswa merupakan faktor utama yang menentukan derajat keaktifan siswa, bila bahan pelajaran yang dipelajari tidak sesuai dengan minat siswa, siswa tidak akan belajar dengan sebaik-baiknya, sebab tidak ada daya tarik baginya. Oleh karena itu, untuk mengatasi siswa yang kurang berminat dalam belajar, guru hendaknya berusaha bagaimana menciptakan kondisi tertentu agar siswa itu selalu butuh dan ingin terus belajar. Dalam artian menciptakan siswa yang mempunyai minat belajar yang besar, mungkin dengan cara menjelaskan hal-hal yang menarik. Bahkan dalam kondisi saat masa pandemic covid-19 saat ini yang mengharuskan siswa harus belajar dirumah, tidak seperti pembelajaranpembelajaran sebelumnya yang berjalan semestinya, dimana dalam kondisi saat ini seorang guru juga harus pintar-pintar dalam menciptakan pembelajaran yang menarik walaupun dengan pembelajaran jarak jauh (daring).

Berdasarkan hasil observasi kelas IV di SDN 1 Wringin Anom yang di lakukan oleh peneliti, peneliti menemukan suatu masalah yaitu masalah yang sering dirasakan sulit serta kurang diminati oleh siswa dalam pembelajaran matematika seperti contoh siswa merasa jenuh dan kesulitan dalam memahami pembelajaran yang di sampaikan oleh guru. Ironisnya matematika termasuk pelajaran yang tidak disukai. Banyak siswa takut akan pelajaran matematika. Bagi mereka matematika seperti musuh yang menakutkan yang ingin sekali mereka hindari. Tidak sedikit siswa yang mengeluh dengan adanya pelajaran matematika. Karena begitu pentingnya pelajaran matematika untuk masa depan bangsa, kita harus memperjuangkan matematika sebagai pelajaran yang menarik, menyenangkan bagi para siswa.

Sehubung dengan alasan dan analisis masalah diatas, maka peneliti mengambil judul “ Analisis Minat Belajar Siswa Pada Materi Konsep Pecahan Matematika Siswa Kelas IV Dalam Masa Pandemi Covid-19 Di SD Wringin 
Anom Kecamatan Jatibanteng Kabupaten Situbondo Tahun Pelajaran 2019/2020."

\section{Metode Penelitia}

Sesuai dengan metode penelitian dan permasalahan yang akan diteliti, penelitian ini merupakan penelitian kualitatif. Pendekatan dan Jenis Penelitian Menurut Sugiyono, metode penelitian kualitatif sering disebut metode penelitian naturalistik karena penelitiannya dilakukan pada kondisi yang alamiah sering disebut juga sebagai metode etnographi, karena pada awalnya metode ini lebih banyak digunakan untuk penelitian bidang antropologi budaya; disebut sebagai metode kualitatif, karena data yang terkumpul dan analisisnya lebih bersifat kualitatif.

Dalam penelitian ini peneliti mengambil jenis penelitian deskriptif dengan pendekatan kualitatif. Penelitian kualitatif mempunyai dua tujuan yaitu pertama menggambarkan dan mengungkapkan kedua menggambarkan dan menjelaskan. Pendekatan kualitatif bersifat deskriptif dikarenakan penelitian deskriptif ditujukan untuk mendeskripsikan dan menggambarkan fenomenafenomena yang ada, baik fenomena yang bersifat alamiah ataupun rekayasa manusia. Penelitian ini juga mengkaji bentuk aktivitas, karakteristik, perubahan, hubungan, kesamaan dan perbedaannya dengan fenomena lainnya. Nana.

\section{Metode Analisis Data}

Sebelum analisisn data dilakukan peneliti terlebih dahulu melakukan metode pengumpulan data, dimana pada proses ini ada tiga tahap yang dilalui guna mendapatkan data yng ingin dperoleh. Pertama ada kegiatan observasi, kedua wawancara, dan yang ketiga dokumentasi.

Analisis data adalah proses mencari dan menyusun secara sistematis data yang diperoleh dari hasil wawancara, catatan lapangan, dan bahan-bahan lain, sehingga dapat mudah dipahami, dan temuannya dapat diinformasikan kepada orang lain. Teknik analisis data pada penelitian ini penulis menggunakan tiga prosedur perolehan data.

\section{Reduksi Data (Data Reduction), proses penyempurnaan data}


2. Penyajian Data (Display) menyajikan data untuk mempermudah pemahaman

3. Verifikasi Data (Conclusions drowing/verifiying) Pengecekan ulang data

Data

1. Data Primer: data yang dieproleh secara langsung melalui proses wawancara.

2. Data Sekunder: data yang diperoleh melalui sumber bacaan atau buku.

\section{Sumber Data}

Diperoleh dari subyek yang dietliti, pada penelitian ini sumber data yaitu seluruh warga sekolah, keluarga dari anak kesulitan belajar di SDN 1 Wringin Anom Kec. Jatibateng Kab. Situbondo.

\section{Reduksi Data}

Reduksi data adalah proses penyempurnaan data, baik pengurangan terhadap data yang dianggap kurang perlu dan tidak relevan, maupun penambahan data yang dirasa masih kurang. Data yang diperoleh di lapangan mungkin jumlahnya sangat banyak. Reduksi data berarti merangkum, memilih hal-hal yang pokok, memfokuskan pada hal-hal yang penting, dicari tema dan polanya. Dengan demikian data yang akan direduksi memberikan gambaran yang lebih jelas, dan mempermudah peneliti untuk melakukan pengumpulan data selanjutnya, dan mencarinya bila diperlukan, Sugiyono .

\section{Penyajian Data/ Display}

Dengan mendisplay atau menyajikan data akan memudahkan untuk memahami apa yang terjadi selama penelitian berlangsung. Setelah itu perlu adanya perencanaan kerja berdasarkan apa yang telah dipahami. Dalam penyajian data selain menggunakan teks secara naratif, juga dapat berupa bahasa nonverbal seperti bagan, grafik, denah, matriks, dan tabel. Penyajian data merupakan proses pengumpulan informasi yang disusun berdasarkan kategori atau pengelompokanpengelompokan yang diperlukan. Miles and Huberman dalam penelitian kualitatif penyajian data bisa dilakukan dalam bentuk uraian singkat, bagan, hubungan antarkategori, flowchart dan sejenisnya. Ia mengatakan "yang paling sering 
digunakan untuk menyajikan data dalam penelitian kualitatif adalah dengan teks yang bersifat naratif" Sugiyono .

\section{Verifikasi Data}

Langkah terakhir dalam teknik analisis data adalah verifikasi data. Verifikasi data dilakukan apabila kesimpulan awal yang dikemukan masih bersifat sementara, dan akan ada perubahan-perubahan bila tidak dibarengi dengan buktibukti pendukung yang kuat untuk mendukung pada tahap pengumpulan data berikutnya. Bila kesimpulan yag dikemukan pada tahap awal, didukung dengan bukti-bukti yang valid dan konsisten saat penelitian kembali ke lapangan mengumpulkan data, maka kesimpulan yang dikemukan merupakan kesimpulan yang kredibel atau dapat dipercaya, Sugiyono .

Dalam penelitian kualitatif, kesimpulan yang didapat kemungkinan dapat menjawab fokus penelitian yang sudah dirancang sejak awal penelitian. Ada kalanya kesimpulan yang diperoleh tidak dapat digunakan untuk menjawab permasalahan. Hal ini sesuai dengan jenis penelitian kualitatif itu sendiri bahwa masalah yang timbul dalam penelitian kualitatif sifatnya masih sementara dan dapat berkembang setelah peneliti terjun ke lapangan.

\section{Pengecekan Keabsahan Temuan}

Pengujian keabsahan data dalam penelitian kualitatif dilakukan dengan uji kredibilitas data, uji depenabilitas data, serta uji konfirmabilitas . Kredibilitas dalam Kamus Besar Bahasa Indonesia diartikan sebagai perihal dapat dipercaya, sedangkan konfirmasi diartikan sebagai penegasan, pengesahan, dan pembenaran. Setelah data diperoleh melalui beberapa sumber dan teknik pengumpulan data, maka langkah selanjutnya dalam penelitian adalah viliditas data, yang bertujuan untuk mengukur dan mengidentifikasi keaslian data yang diperoleh.

Validitas merupakan derajat ketepatan antara data yang terjadi pada objek penelitian dengan daya yang dapat dilaporkan oleh peneliti. Dengan demikian, kevalitan data merupakan pembuktian bahwa penelitian tersebut Untuk membuktikan keabsahan data penelitian, maka dibutuhkan beberapa 
pengujian melalui metode penelitian. Pertama, uji kredibilitas diartikan kepada kapasitas seseorang atau data yang memiliki kapasitas memadahi. Dalam penelitian, kredibilitas lebih ditekankan pada kualitas dan kapasitas data yang diperoleh. Sugiyono, uji kredibilitas keabsahan data meliputi beberapa aspek: pertama, aspek perpanjangan pengamatan, yaitu peneliti kembali ke lapangan untuk lebih meluas mencari informasi lagi. Kedua, meningkatkan ketekunan dimana peneliti melakukan pengamatan harus secara cermat dan berkesinambungan. Ketiga, triangulasi sumber dan teknik penelitian. Triangulasi diartikan sebagai pengecekan data dari berbagai sumber, berbagai cara, dan berbagai waktu .

Pada penelitian ini di SDN 1 Wringin Anom, disamping peneliti melakukan wawancara, peneliti juga melakukan observasi dalam rangka untuk memperkuat data. Dalam hal ini, peneliti secara satu persatu mengecek setiap siswa terkait gaya belajar siswa. Cara pengecekan tersebut, pertama peneliti langsung terjun ke lapangan, dengan mewawancarai kepada siswa tersebut. Kedua, uji transferebiliti yaitu kevalitan data ketika dibandingkan dengan data lainnya. Transferbility berasal dari dua kata, transfer yang artinya pindah dan ability yang artinya kemampuan. Sehingga transferbility diartikan sebagai kemampuan penilaian data yang dapat digunakan dalam situasi lain. Pengujian transferbility merupakan pengujian data, dimana data yang diperoleh dapat diterapkan dalam situasi apa pun dan data tersebut memiliki nilai-nilai yang dapat dijadikan acuhan oleh peneliti lainnya.

Sebagai bentuk pengujian keabsahan data dalam penelitian di SDN 1 Wringin Anom, peneliti mengaitkan hasil penelitian dengan penelitian lainnya yang sekiranya ada kesamaan. Sehingga dengan pengaitan data tersebut, peneliti dapat menilai sampai dimana validitas keabsahan data dalam penelitian ini. Uji depenabilitas dilakukan dengan melakukan audit terhadap keseluruhan proses penelitian, sedangkan uji konfirmabilitas dilakukan dengan menguji hasil penelitian dikaitkan dengan proses yang dilakukan. Uji depenabilitas dalam penelitian ini merupakan proses pembimbingan dari penentuan fokus masalah hingga penarikan kesimpulan. 
Uji konfirmabilitas merupakan uji obyektivitas penelitian. Uji konfirmabilitas dalam penelitian kualitatif mirip dengan uji depenabilitas sehingga pengujiannya dapat dilakukan secara bersamaan. confirmability menurut Zainal Arifin yaitu apakah hasil penelitian dapat dibuktikan kebenarannya di mana hasil penelitian sesuai dengan data yang dikumpulkan dan dicantumkan dalam laporan lapangan. Pada penelitian ini di SDN 1 Wringin Anom, uji konfirmabilitas dilakukan dengan pelampiran berbagai data-data yang diperoleh saat penelitian.

\section{Pembahasan Penelitian}

Berdasarkan hasil penelitian yang di lakukan di SD 1 Wringin Anom tentang Minat belajar Matematika pada materi konsep pecahan, di era pandemi Covid-19 peneliti melakukan wawancara terhadap guru kelas yang sekaligus menjadi guru matematika di kelas 4 SD negeri 1 wringin Anom kecamatan Jati Banteng, wawancara yang di teliti tentang minat belajar di antaranya: Faktor internal dan Faktor eksternal yang di alami siswa.

1. Faktor Internal

Factor internal minat belajar siswa terdiri dari dua bagian yaitu jasmani dan psikologis.

a. Aspek Jasmaniah

Aspek jasmaniah mencakup kondisi fisik atau kesehatan jasmani dari individu siswa. Kondisi fisik yang prima sangat mendukung keberhasilan belajar dan dapat mempengaruhi minat belajar, begitu pula sebaliknya.

b. Aspek Psikologis (kejiwaan)

Aspek psikologis (kejiwaan), faktor psikologis meliputi perhatian siswa ketika guru menjelaskan, pengamatan siswa ketika guru meminta untuk mengamati, tanggapan siswa pada saat guru bertanya, ingatan siswa ketika guru melakukan Tanya jawab, cara berfikir siswa pada saat guru memberikan soal-soal, serta bakat atau kemampuan yang dimiliki oleh siswa pada pembelajaran.

2. Faktor Eksternal

Faktor eksternal merupakan faktor yng berasal dari luar diri siswa yang meliputi lingkungan keluarga (Perhatian dari orang tua), lingkungan sekolah 
(Pembelajaran Jarak Jauh harus dilakukan saat pandemi Covid-19 seperti ini, rasa bosan bias saja menghampiri siswa sehngga tidak ada minat belajar), guru dan cara mengajarnya dan sarana prasarana. Berikut ini merupakan faktor eksternal dari minat belajar siswa.

\section{Kesimpulan}

Berdasarkan hasil analisis dan pembahasan yang dipaparkan pada bab 4 dapat disimpulkan bahwa analisis minat belajar Matematika pada materi konsep pecahan di kelas 4 SD Negeri 1 Wringin Anom Kecamatan Jatibanteng dapat di pengaruhi beberapa faktor yaitu faktor internal dan faktor eksternal. Faktor internal meliputi faktor fisiologi dan faktor psikologi sedangkan faktor eksternal meliputi lingkungan keluarga, lingkungan belajar pada saat kegiatan luring. Dari faktor eksternal yang mempengaruhi adanya minat belajar siswa dari lingkungan keluarga berupa perhatian orang tua, lingkungan belajar pada saat kegiatan luring berupa kedisiplinan yang harus diterapkan pada saat kegiatan luring dilaksanakan.

Dari faktor-faktor tersebut harus diberikan penanganan yang khusus agar peserta didik memahami untuk pembelajaran matematika hususnya pada materi konsep pecahan, tidak adanya minat belajar yang dialami oleh peserta didik didalam pembelajaran Matematika materi konsep pecahan pada akhirnya dapat diketahui dan ditemukan secara sistematis yang berlokasi di SD Negeri 1 Wringin Anom Kecamatan Jatibanteng Kabupaten Situbondo tahun ajaran 2020/2021.

\section{Saran}

1. Bagi guru

Guru harus dapat memberikan perhatian dan motivasi ekstra bagi siswa agar minat belajar siswa tetap ada pada diri setiap siswa.

2. Bagi Sekolah

Sekolah harus menyediakan semua kebutuhan siswa dalam menunjang proses pembelajaran terutama pada saat pandemic Covid.

3. Bagi peneliti selanjutnya

Diharapkan dapat memberikan wawasan dan masukan serta bahan tambahan dalam penelitian selanjutnya. 